\section{NEINVAZIVNÍ MĚŘENÍ NITROLEBNÍHO TLAKU METODAMI DIFERENCIÁLNÍ GEOMETRIE}

\section{Arnošt Mládek, Václav Gerla, Petr Šeba, Petr Skalický, Vladimír Beneš, Ondřej Bradáč}

\begin{abstract}
Abstrakt
Kontinuální monitorace nitrolebního tlaku je v neurointenzivní péči naprosto klíčová. Přestože bylo navrženo množství alternativních metod, invazivní měření ICP pomocí katetru představuje široce uznávaný zlatý standard. Invazivní měření tlaku likvoru v mozkovém parenchymu nebo postranních komorách je však spojeno s rizikem vzniku infekce, hematomu nebo záchvatů. Uvedené komplikace měření nitrolebního tlaku jsou tak motivací pro studium neinvazivních přistupů. Námi navržená metodologie neinvazivního měření nitrolebního tlaku je založena na výpočtu diferenciálně geometrických invariantů mikro-pohybů hlavy u komatózních pacientů a její potenciál spočívá v možnosti kontinuálního měření nitrolebního tlaku v rámci konzervativní léčby mozkových traumat. Domníváme se, že navržený postup měření přesahuje hranice traumatické neurochirurgie a bylo by možné jej aplikovat i v jiných oblastech medicíny.
\end{abstract}

\section{Klíčová slova}

nitrolební tlak, ICP, dICP, mozkomíšní mok, CSF, diferenciální geometrie, Cartanova křivost, neinvazivní měrení

\section{1 Úvod}

Zvýšená hodnota nitrolebního tlaku (ICP) představuje emergentní situaci v neurochirurgii. Do etiologie vzniku nitrolební hypertenze spadají mozková traumata (TBI), nitrolební léze, poruchy cirkulace mozkomíšního moku (CSF) a různé patologické difuzní procesy v nitrolebí. Schopnost kontinuální a přesné monitorace ICP je klíčová pro časnou detekci sekundárního poškození mozku a k nasazení akutní intervenční léčby. Zlatým standardem měření ICP je kraniektomie a následné zavedení katetru do oblasti mozkového parenchymu nebo postranních komor. Tento postup je však neoddělitelně spjat $s$ rizikem zanesení infekce, rozvojem meningoencefalitidy nebo vznikem nitrolebního krvácení. Potenciální přínos robustní a spolehlivé neinvazivní metody měření ICP by byl naprosto zásadní pro traumatickou neurochirurgii a neurointenzivní péči.

Navržené a publikované postupy neinvazivního měření ICP bohužel stále nedosahují požadované přesnosti nebo nesplňují požadavek na možnost dlouhodobé kontinuální monitorace. $\checkmark$ recentním přehledovém článku neinvazivních postupů měření ICP Canac et al. ${ }^{1}$ rozdělil metody dle použité modality na oftalmické, otické, elektrofyziologické a metody měření fluidní dynamiky. Do oftalmických metod spadá např́klad ultrazvukové měření expanze pochvy optického zrakového nervu při zvýšeném ICP2, venózní oftalmodynamometrie ${ }^{3}$ postavená na principu závislosti ICP na průsvitu centrální retinální žíly, měření prostřednictvím optické koherenční tomografie ${ }^{4}$ nebo pupilometrie $^{5}$. Otické metody jsou založeny na existenci komunikace mezi likvorovými a perilymfatickými prostory a na měření otoakustických emisí, jejichž intenzita koreluje s ICP6-8. Elektroencefalografické studie prokázaly signaturní změny předcházející elevaci ICP9 ${ }^{9}$ nicméně statistická signifikance korelačních koeficientů je předmětem diskuse ${ }^{9,10}$. Stran přístupů založených na fluidní dynamice, transkraniální dopplerovské měření bylo použito pro odhad ICP ${ }^{11-13}$, univerzální předpis pro výpočet ICP však nebyl odvozen a jednotlivé odhady se tak liší. ${ }^{14}$ Uvedený přehled alternativních metod pro odhad ICP zdaleka není vyčerpávající a bližší informace je možné najít v přehledovém článku
Canac et al. ${ }^{1}$ Ačkoliv jsou navržené neinvazivní postupy důmyslné a inspirativní, $\mathrm{k}$ jejich nasazení v klinické praxi doposud nedošlo. Jsou využívány $v$ experimentálním režimu nebo jako screeningové doplňkové metody.

\section{Metody}

\subsection{Teorie}

Během systolické fáze je krev vypuzena ze srdce do nitrolebí. Proud krve reprezentovaný tlakovou vlnou (pulsem) šírící se podél artérií je spojen s hybností, kterou Ize podle zákona zachování hybnosti pouze transformovat do dalších fyzikálních procesů, přičemž expanze lebky je jedním z nich. Větvícími se arteriemi se krev dostává postupně k lebeční klenbě a částečně se odráží na vnitřním povrchu krania. Hybnost odražené krve je přenesena na lebeční kosti, což vede k mírnému pohybu hlavy, který je možné detekovat. Vzhledem k tomu, že větvení tepen není zcela symetrické vzhledem $\mathrm{k}$ ose těla, představuje mikroskopický pohyb hlavy velmi složitý proces, jehož podkladem je superpozice všech odrazů pulzních vln uvnitř lebky.

V námi navrženém přistupu ${ }^{15}$ používáme vlastní polštář se zabudovanými mechanickými senzory. Polštáŕ měří projekce pohybů hlavy ve směrech kolmých na jednotlivé senzory. Z elektroniky polštáře tak získáváme pohyby hlavy při pohledu ze souřadnicového systému souvisejícího s jednotlivými senzory.

Mechanické procesy uvnitř lebky mohou být reprezentovány multidimenzionální křivkou $\beta$ - geometrickým objektem, který globálně popisuje pohyb hlavy. Každý senzor v polštáři poskytuje jednorozměrnou projekci pohybu hlavy a představuje príslušnou složku $\beta v$ daném směru. Zatímco posunutí senzorů vzhledem $k$ hlavě inherentně mění jednotlivé komponenty, vlastní křivka $\beta$ zůstává stejná, nebot změna polohy polštáře nemá žádný vliv na procesy $v$ lebce (pozorujeme jen pohyb hlavy z jiného úhlu). Zjednodušeně řečeno, multidimenzionální křivka $\beta$ představuje "otisk prstu" intrakraniálních mechanických procesů, ze kterých Ize v principu odvodit dynamiku CSF.

Podle diferenciální geometrie pro danou hladkou n-rozměrnou křivku $\beta$ existují přesně $n-1$ funkcí $\mathrm{k}_{1}(\mathrm{t}), \mathrm{k}_{2}(\mathrm{t}), \ldots, \mathrm{k}_{\mathrm{n}-1}(\mathrm{t})$, které křivku zcela definují. Tyto funkce se označují jako Cartanovy křivosti a lze je vypočítat $z$ naměěených jednorozměrných signálových projekcí. Funkce $k(t)$ predstavují tzv. euklidovské invarianty, které se nemění s pohybem hlavy, a to i přesto, že jsou vypočíány $z$ projekcí závislých na poloze hlavy. $V$ rámci námi navržené metody se omezujeme na první křivost $\mathrm{k}_{1}(\mathrm{t})$, a to $\mathrm{z}$ následujících důvodů: i) komponenta $\mathrm{k}_{1}(\mathrm{t})$ je funkcí pouze druhých derivací naměřeného signálu, a proto není přiliš citlivá na šum, současně však nese dostatek informací o zkoumaném procesu. ii) výpočet vyšších křivostí $k_{n}(t)$ pro $n>1$ vychází ze znalosti derivací $n+1$ řádu, které jsou výrazně citlivější na šum.

\subsection{Měření}

Experimentální zapojení je znázorněno na Obr. 1. Synchronně bylo monitorováno a zaznamenáváno pro následné zpracování 6 signálů: EKG, referenční ICP měřené parenchymálním katetrem a mechanické signály pohybů hlavy registrované čtyřmi tlakovými senzory zabudovanými do polštáře. Vzorkovací frekvence byla $1 \mathrm{kHz}$, analogové signály byly digitalizovány 12 bitovým A/D prevodníkem.

\subsection{Analýza signálů}

Proces zpracování signálu je znázorněn na Obr. 2. Z mechanických signálů, které reprezentují čtyřrozměrnou $\beta$ křivkou, vypočítáme první Cartanovu křivost $\mathrm{k}_{1}(\mathrm{t})\left(\mathrm{ADC} \cdot \mathrm{ms}^{-2}\right.$, kde $\mathrm{ADC}$ představuje jednotku převodníku), která je z definice nezáporná. Každý peak $\mathrm{k}_{1}(\mathrm{t})$ odpovídá konkrétnímu pohybu hlavy detekovanému $v$ čase $t$. 
Typická ICP vlna obsahuje tři maxima označené P1 - P3. I když je interpretaci těchto maxim věnována $v$ literatuře značná pozornost (Obr. 2A, červené tečky), z pohledu naší metody jsou podstatně zajímavější extrémy časové derivace ICP (dICP) [mmHg. $\left.\mathrm{ms}^{-1}\right]$ (Obr. 2A, modré tečky), nebot' právě to jsou okamžiky, kdy dynamika CSF vrcholí a tlaková vlna se odráží od lebky. V okamžiku maxima ICP, tj. okamžiku P1 - P3, dICP je z definice rovno 0 - jedná se tak o okamžik, kdy je ICP v rovnováze a z pohledu dynamiky se „nic neděje“.

Dynamika CSF je úzce spjata se srdečním cyklem. Z tohoto důvodu jsme ve studii použili time-locking metodu, v rámci které jsou signály $\mathrm{k}_{1}(\mathrm{t}) \mathrm{i}$ dICP segmentovány na základě $\mathrm{R}$-kmitu do takzvaných elementárních intervalů (EI). $\mathrm{N}$-tý El začíná v době n-tého R-kmitu $\left(t_{n}\right)$ a končí v $t_{n}+500$ ms (Obr. 2A, plné a přerušované zelené svislé čáry).

Signály $\mathrm{k}_{1}(\mathrm{t})$ a dICP jsou fragmentovány na N 500 ms dlouhých El. Hodnoty $\mathrm{k}_{1}(\mathrm{t})$ a dICP $\vee$ každém intervalu jsou normalizovány a mapovány pomocí stupnice šedi (černá: 0 , bílá: 1) (Obr. 2B, $\mathrm{k}_{1}(\mathrm{t})$ : modrý obdélník, dICP: oranžový obdélník). Barevně kódované proužky se poté otočí o $90^{\circ}$ ve směru hodinových ručiček a spojí se vodorovně vedle sebe zleva doprava. Získáme tak alternativní reprezentaci $\mathrm{k}_{1}(\mathrm{t})$ a dICP - Cartanovu a dICP mapu (Obr. $2 \mathrm{C})$, kde osa x představuje index El s $\mathrm{n} \in\{0,1, \ldots, \mathrm{N}\}$, osa y představuje relativní čas t v intervalu $\mathrm{t} \in(0,500) \mathrm{ms}$. Na Cartanových mapách vidíme variabilní počet pásem maxim (pásy bílé barvy), z nichž každý je spojen s nějakou mechanickou událostí, ke které dochází přibližně ve stejnou dobu $v$ rámci srdečního cyklu. Analogické dICP mapy mají obecně nižší počet pásem maxim, přičemž první maximum je zpravidla nejvýznamnější.

\subsection{Přehled měřených pacientů}

Do studie bylo zahrnuto 24 pacientů (P01-P24); 21 mužů a 3 ženy s průměrným věkem $47,3 \pm 18,5$ (Tab. 1). GCS při př́ijmu se pohybovalo v rozmezí 3 - 15 s mediánem 3 a IQR $3\left(Q_{3}=6\right.$, $\left.Q_{1}=3\right)$. Pacienti byli přijati na urgentní př́ijem Vojenské fakultní nemocnice $v$ Praze $s$ podezřením na izolované TBI nebo jako součást polytraumatu. Všichni pacienti podstoupili standardní klinické a laboratorní vyšetření, byl proveden UZ břicha a CT celého těla včetně $C T$ angiografie mozku. Po počáteční léčbě bezprostředně život ohrožujících stavů byli pacienti umístěni na JIP k dalšímu sledování. Všichni pacienti měli vstupní a následné neurologické vyšetření a CT mozku. Pacienti se známkami nitrolební hypertenze, ale bez indikace k okamžitému chirurgickému zákroku, byli indikováni k intraparenchymálnímu monitorování ICP. Průměrné počáteční ICP bezprostředně po zavedení katetru bylo $15,5 \pm 9,0 \mathrm{mmHg}$. ICP katetr byl zaveden přes pravou prefrontální kưru, s výjimkou př́padů, kdy bylo z jiných důvodu nutné umístění do levé prefrontální kưry (lokalizované expanze - kontuze, krvácení, ischemie nebo známá dominance pravé hemisféry). Po operaci byl pod hlavu pacienta umístěn polštář vybavený mechanickými senzory (Obr.1).

\subsection{Korelační analýza}

Proces korelační analýzy je znázorněn v podobě vývojového diagramu na Obr. 3. Cartanova křivost $k_{1}(t)$ je počítána výhradně $\mathrm{z}$ mechanických dat; dICP představuje časovou derivaci referenčního signálu ICP. Time-locking segmentace na základě EKG a uspořádání El proužků vedle sebe umožňuje reprezentaci $\mathrm{k}_{1}(\mathrm{t})$ a dICP ve formě mapy. Průběh hran (bílá pásma lokálních maxim) jsou semi-automaticky detekována $v$ obou mapách (Obr. 3, oranžové křivky). Vybrané křivky páru $\mathrm{k}_{1}(\mathrm{t})$ - dICP jsou pak korelovány.

\section{Výsledky a diskuse}

Celkem jsme získali přibližně 574 hodin signálů z celkového počtu 24 komatózních pacientů s TBI (Tab. 2). Data byla analy- zována pomocí MATLAB kódu navrženého tak, aby vyhledával nejdelší nepřerušované segmenty s minimální délkou 5000 po sobě jdoucích El. Trvání nejkratšího segmentu složeného z 5 $000 \mathrm{El}$ je přibližně 1,2 hodiny při průměrné srdeční frekvenci 70 tepů za minutu. Počet segmentů nalezených v záznamu každého pacienta se pohyboval mezi 1 (P11, P13, P17, P23) a 11 (P16). Průměrný počet segmentů na pacienta byl 4,5 . Celkový počet segmentů všech pacientů byl 108 a průměrná délka segmentu byla více než 100000 El (přibližně 24 hodin). Pro každý segment byla vypočtena príslušná $\mathrm{k}_{1}(\mathrm{t})$ a dICP mapa a analyzována semi-automatickým algoritmem detektoru hran.

Na dICP mapách lze rozeznat až tři pásma maxim, přičemž první je nejvýraznější a nejlépe definované. První maximum dICP Ize detekovat v rozsahu 60 - 180 ms v každém El a je spojeno s nejrychlejším nárůstem ICP směrem $\mathrm{k}$ vrcholu $\mathrm{P} 1$. V souladu s vyšší variabilitou výskytu P2 a P3 maxim v signálu ICP jsou jejich odpovídající pásma méně výrazná a často rozmazaná. Počet a rozložení maxim na $k_{1}(t)$ mapě je ve srovnání $s$ dICP heterogenní a pacient-dependentní, přesto existuje několik charakteristik, které jsou zřejmě univerzální. U každého pacienta jsme identifikovali pásmo $k_{1}(t)$ maxim $v$ časovém intervalu $\left(t_{n}\right.$ $\left.+50 \mathrm{~ms}, \mathrm{t}_{\mathrm{n}}+200 \mathrm{~ms}\right)$, které se tvarem a časem nástupu shoduje s prvním maximem dICP.

Pomocí detektoru hran byly křivky spojující př́slušná $k_{1}(t)$ a první maxima dICP vypočítány samostatně pro každý segment. Pearsonův korelační koeficient mezi časem maxima $k_{1}(t)$ a časem prvního maxima dICP v každém ze 108 segmentů je mezi 0,62 (P12/S02) a 0,94 (P05/S08). Střední korelační koeficient zprůměrovaným přes všechny segmenty je $0,74 \pm 0,08$ (Tab. 2). Dále jsme provedli lineární regresní analýzu. Průměrná směrnice lineární regrese pro všechny segmenty je 0,86 0,27. Korelace mezi pásmy maxim $\mathrm{k}_{1}(\mathrm{t})$ a dICP $\vee$ každém segmentu je znázorněna na Obr. 4, korelace pro všechny pacienty a segmenty na Obr. 5.

Vizualizace geometrických invariantů vícerozměrných mechanických signálů společně s time-locking metodou aplikovanou na synchronně měřené EKG představuje originální způsob, jak získat hlubší vhled do intrakraniálních fyzikálních procesů. $\mathrm{Z}$ teoretického hlediska každé maximum $\mathrm{k}_{1}(\mathrm{t})$ odpovídá nějaké mechanické události, jejíž projev prostřednictvím změny tlaku je rozpoznán senzory. Výhodou zobrazování výsledků prostřednictvím map je, že procesy závislé na srdečním cyklu se prezentují jako jasné pásy maxim, zatímco šum nezávislý na srdečním cyklu interferující se signálem je zobrazen jako rozptýlené bílé body.

Na rozdíl od dICP vykazují Cartanovy $\mathrm{k}_{1}(\mathrm{t})$ mapy několik pásem maxim, a to $v$ celém intervalu 0-500 ms. Každý pás maxim $\mathrm{k}_{1}(\mathrm{t})$ souvisí s nějakým opakujícím se procesem, který vzniká vždy $v$ podobném čase od nástupu systoly. $K$ jednoznačnému přiřazení pásma danému fyzikálnímu procesu však stále nemáme veškeré potřebné informace. Navíc se ukazuje, že celkový počet detekovaných maxim je závislý na pacientovi, což souvisí pravděpodobně $s$ anatomickými variacemi. Přestože je nutný další výzkum, aby bylo možné plně porozumět a spojit rekurentní maxima s př́slušnými fyziologickými procesy, existuje několik vzorců, které jsou pozorovatelné u všech pacientů. Domníváme se, že je účelné se omezit na podinterval $\left(t_{n}+50 \mathrm{~ms}, t_{n}+200 \mathrm{~ms}\right)$ $\mathrm{z}$ následujícího důvodu: $\mathrm{k}_{1}(\mathrm{t})$ maxima vyskytující se před tn +50 ms nejsou spojena s intrakraniálním procesem, nebot' 50 ms príliš brzy na to, aby se tlaková vlna dostala do lebeční dutiny. Tato předčasná maxima lze pravděpodobně přiřadit izovolumetrické kontrakci komor, otevření aortální chlopně a ejekci krve do aortálního oblouku nebo možnému odrazu na karotidovém sinu. Kromě toho existuje neurčitý počet superponovaných maximálních pásem před $t_{n}+50 \mathrm{~ms}$, což podporuje náš předpoklad přetrvávajícího šumu. Podobná situace nastává po $\mathrm{t}_{\mathrm{n}}+200 \mathrm{~ms}$. 
Příslušná pozdní maxima $k_{1}(t)$ jsou často rozmazaná, nejasně oddělená a obtížně analyzovatelná. Zdá se, že vzhled Cartanovy mapy po $t_{n}+200$ ms vyplývá ze superpozice dynamiky CSF $s$ dalšími mimolebními procesy, jako jsou sekundární tlakové vlny odrážející se od velkých arteriálních bifurkací v dolní části těla a vibrace přenesené do hlavy prostřednictvím míchy.

Nedostatkem popsané metody neinvazivního měření dynamiky ICP je náchylnost mechanického signálu k vnějšímu rušení. Kvalita mechanických dat zaznamenaných vysoce citlivými tlakovými senzory je často snižena $v$ důsledku 1) interference $s$ vibracemi přenášené na pacienta mechanickou plicní ventilací, 2) suboptimální orientace hlavy pacienta vzhledem k polštáři vedoucí k nerovnoměrně rozloženému zatížení senzorů a 3) manipulace s pacientem pracovníky intenzivního oddělení. Je však třeba poznamenat, že manipulace s pacientem ovlivňuje také měření invazivního ICP, a že přechodné snížení kvality signálu nesnižuje jasný klinický prínos při sledování vývoje ICP v časovém řádu minut až hodin.

Ačkoliv to není předmětem této studie, máme silné indicie, že čas maxima dICP (a tedy $k_{1}(t)$, které $s$ dICP koreluje, viz. výše) lineárně antikoreluje se střední hodnotou ICP (Obr. 2C), takže pokud ICP roste, první maximum dICP se objeví dříve po nástupu systoly. Podle naší hypotézy vyšší ICP vede ke kompresi cerebrálních tepen, což vede k efektivnímu zvýšení tuhosti jejich stěn. $V$ důsledku toho je šíření tlakové vlny rychlejší, a proto pozorujeme mírný negativní časový posun maxima dICP. Podobné časové posuny ve stejném směru Ize pozorovat i u druhého a třetího maxima dICP, která se zdají být ještě citlivější na změnu průměrného ICP. Dynamiku ICP Ize tedy v principu monitorovat sledováním pohybů hlavy a jejich relativních časových poloh v rámci srdečního cyklu.

\section{Závěr}

$\checkmark$ rámci předkládané studie se nám podařilo navrhnout teoretický rámec, zkonstruovat funkční řešení a na souboru 24 pacientů ověřit novou metodu neinvazivního měření nitrolebního tlaku. Metoda je založena na postulátech diferenciální geometrie, zkoumaná multidimenzionální křivka představuje časový vývoj pohybů hlavy měřený maticí tlakových senzorů umístěných v polštáři. Metoda dále využívá time-locking principu, který pro přirozenou segmentaci naměřených signálů využívá synchronně měřené EKG, konkrétně okamžik $R$ kmitu. Prokázali jsme lineární vazbu mezi invariantem křivky, první Cartanovou křivostí, a prvním maximem časové derivace ICP. Domníváme se, že navržený postup má značný přesah a že je možné ho aplikovat pro monitoraci mechanických událostí v těle i v jiných oblastech medicíny.

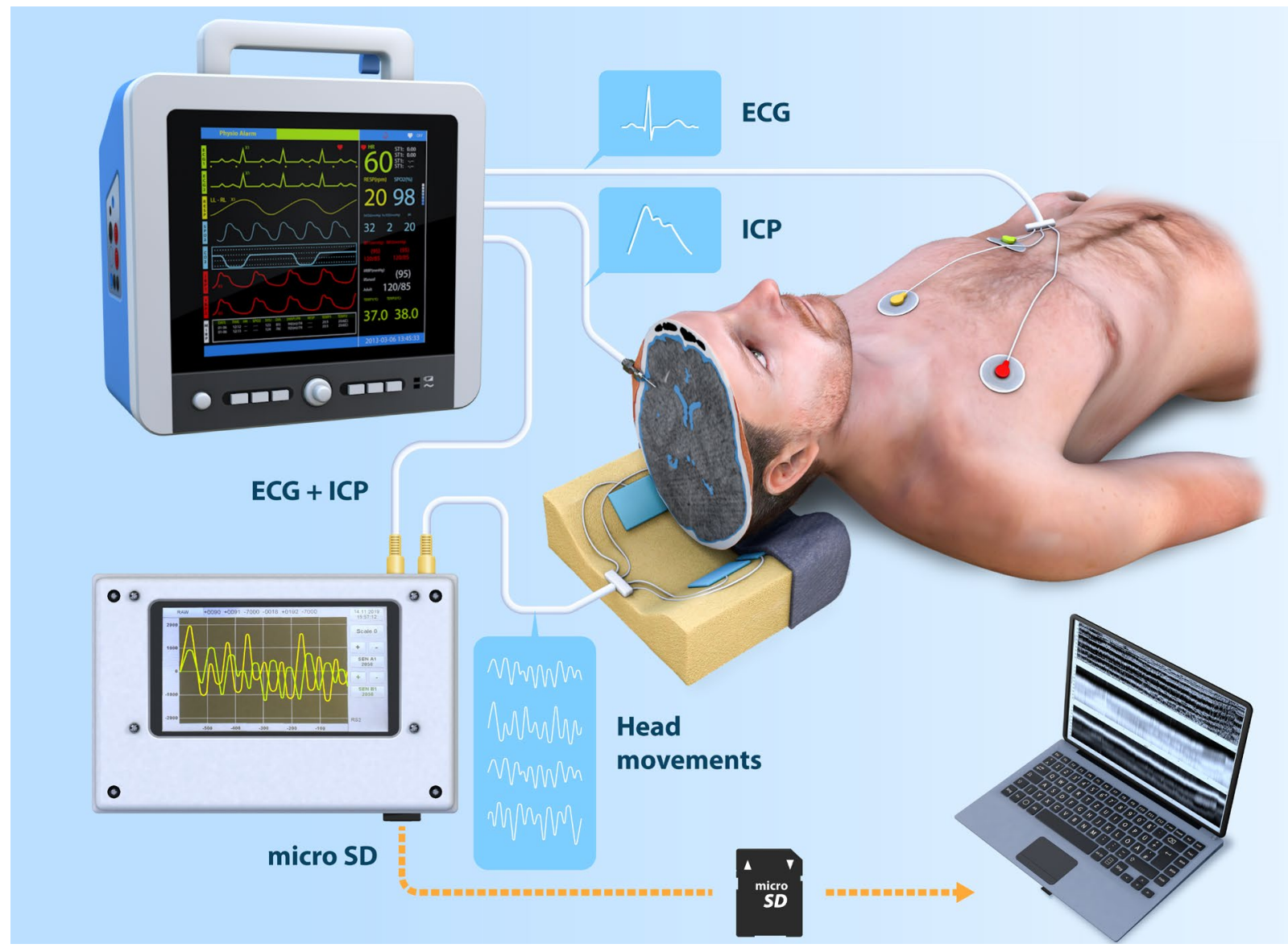

Obrázek 1 - Schéma zapojení. Pohyby hlavy jsou detekovány pomocí 4 tlakových senzorů zabudovaných do polštáre. EKG a referenční hodnota ICP byla získána z lékařského monitoru. 
A.

B.

Head movements
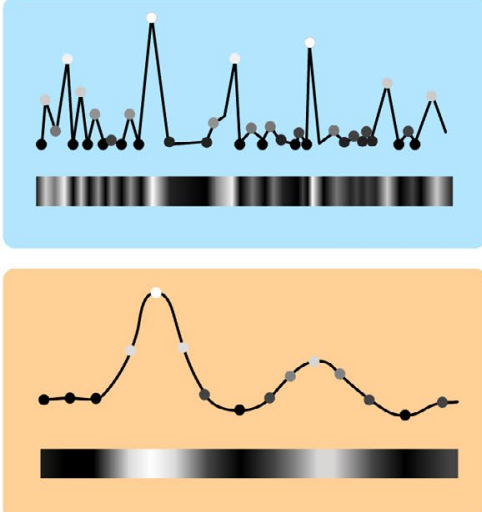

$\min$

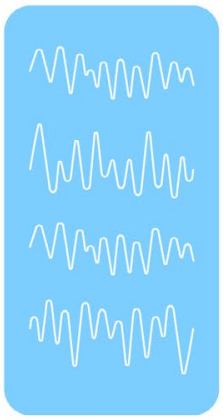

$\frac{d}{d t}$

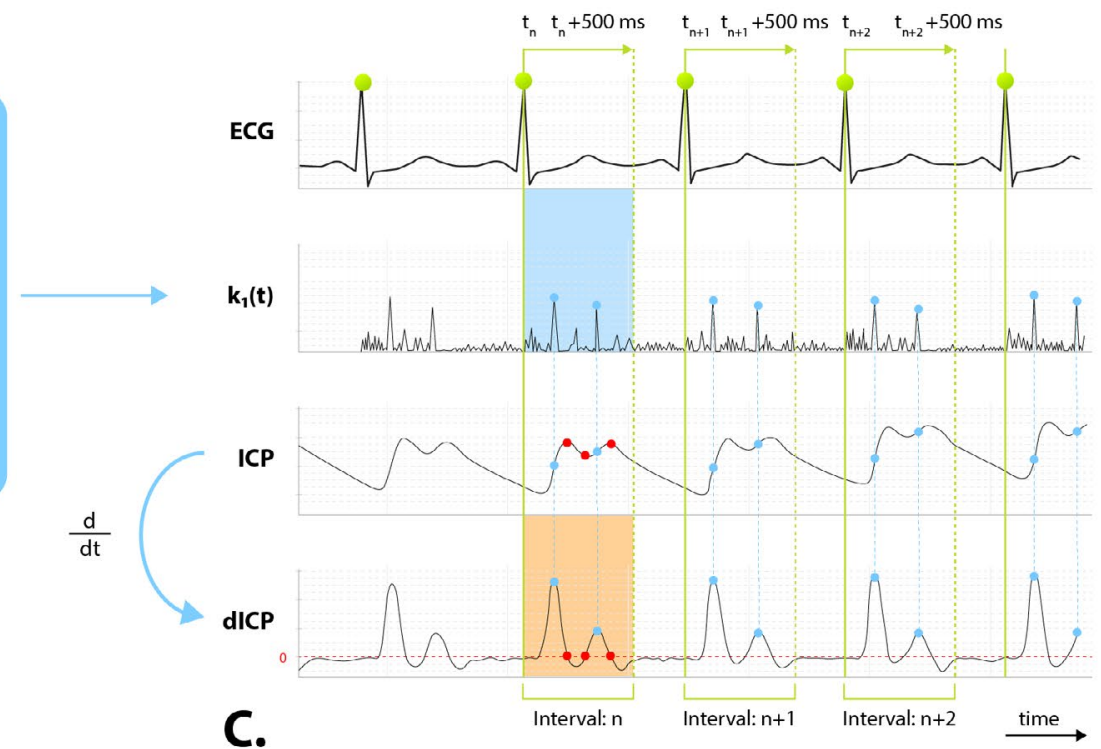

C. Interval



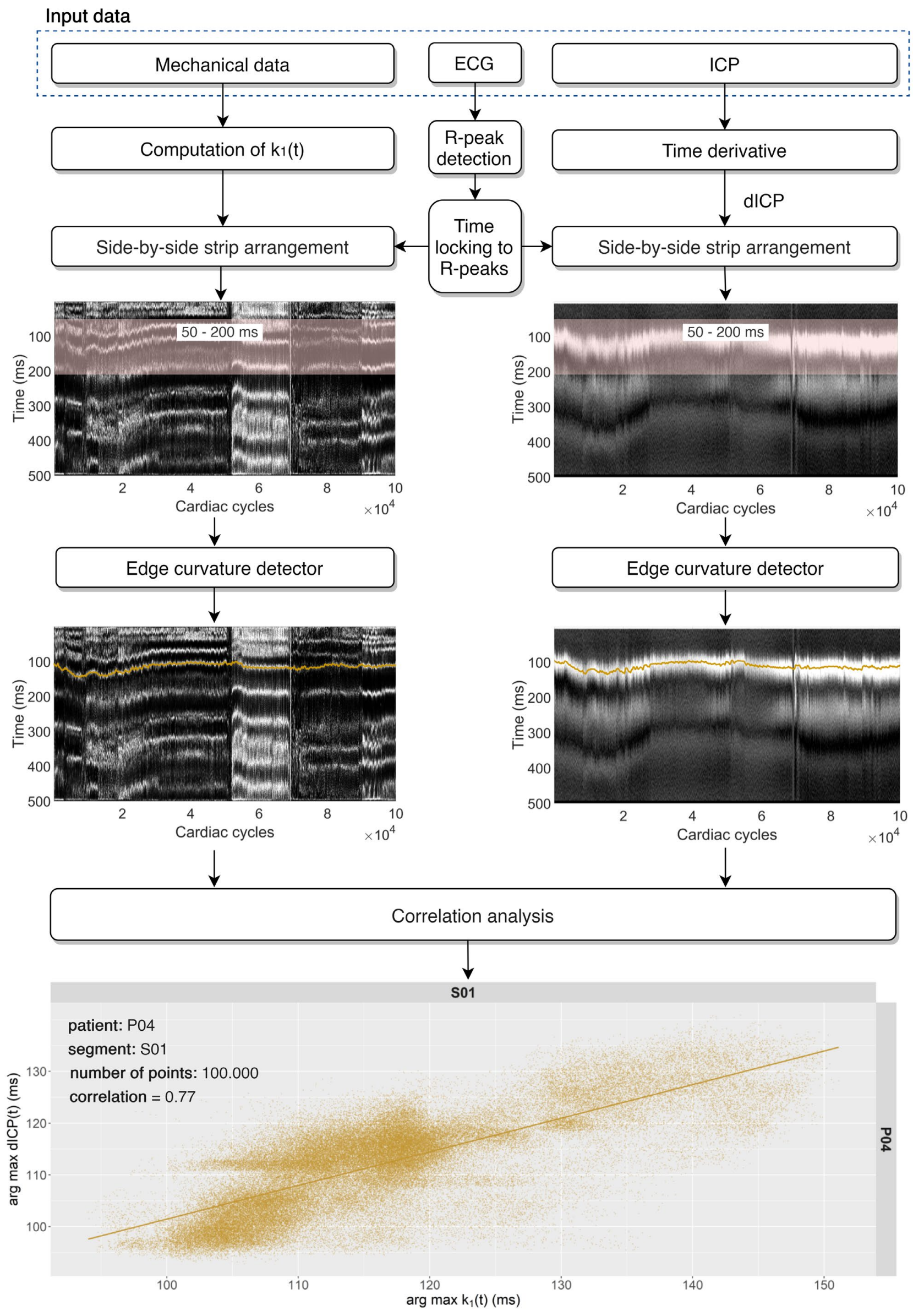




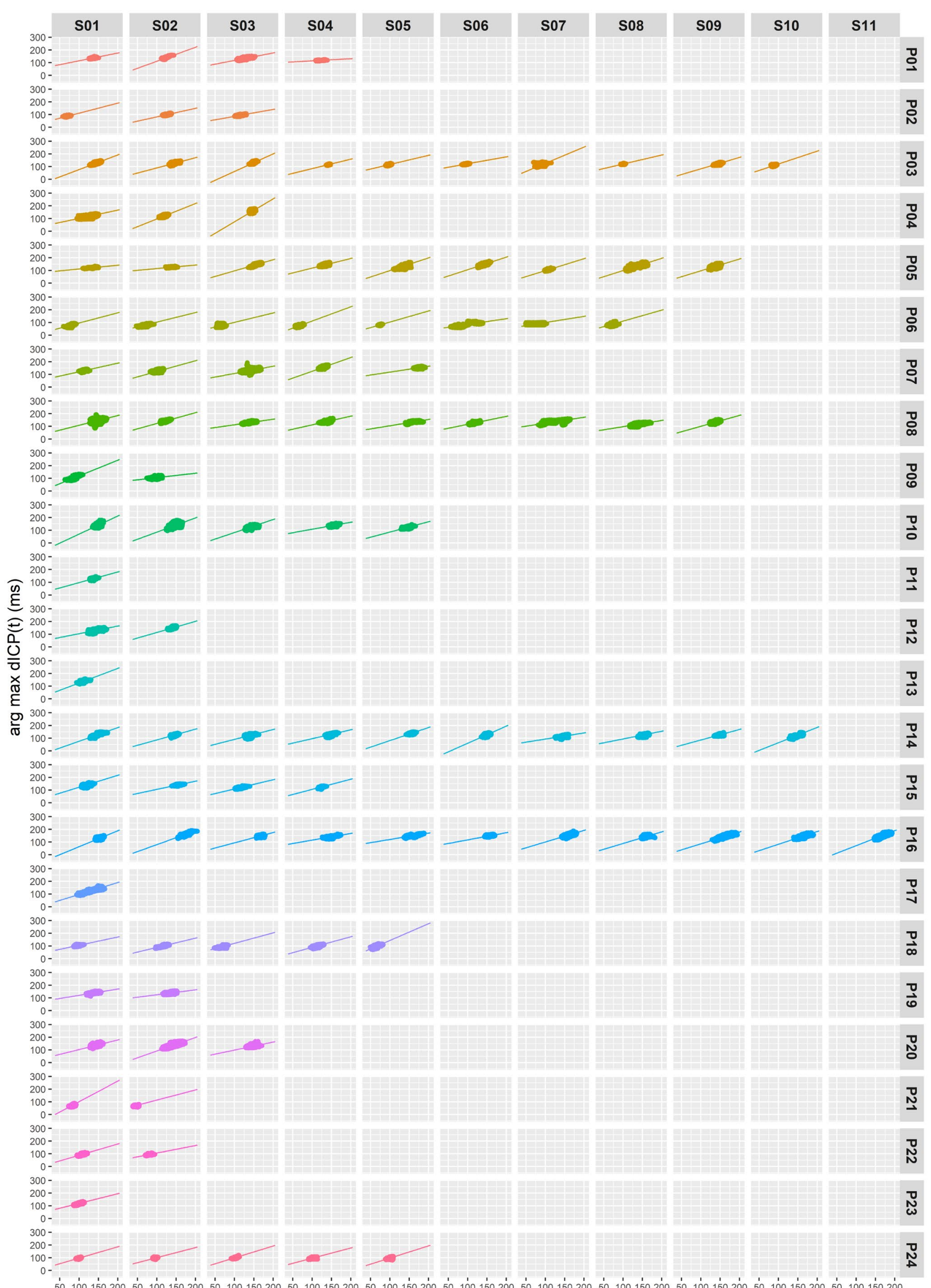

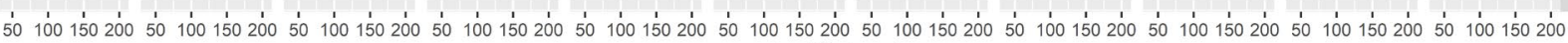
$\arg \max k_{1}(\mathrm{t})(\mathrm{ms})$ 


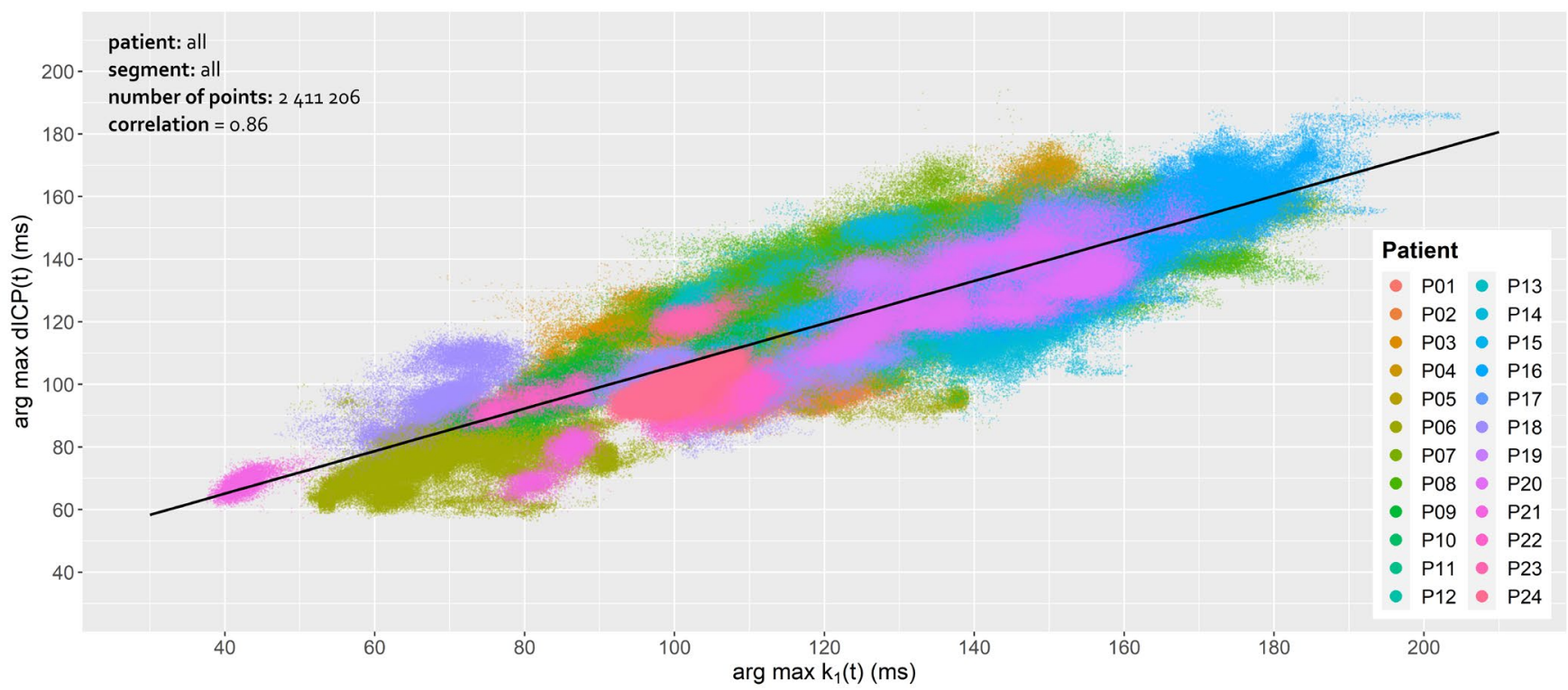

Obrázek 5 - Korelační analýza mezi $k_{1}(t)$ a dICP pro všechny pacienty

\begin{tabular}{|c|c|c|c|c|c|}
\hline Pacient & Pohlaví & Věk & $\begin{array}{l}\text { Marshallovo } \\
\text { skóre }\end{array}$ & $\begin{array}{l}\text { GCS při } \\
\text { př́imu }\end{array}$ & $\begin{array}{c}\text { Iniciální ICP } \\
(\mathrm{mmHg})\end{array}$ \\
\hline P01 & $M$ & 29 & II & 3 & 16 \\
\hline P02 & $\mathrm{F}$ & 67 & III & 3 & 21 \\
\hline P03 & $M$ & 32 & II & 15 & 15 \\
\hline P04 & $\mathrm{F}$ & 66 & III & 4 & 15 \\
\hline P05 & $M$ & 68 & III & 3 & 15 \\
\hline P06 & $M$ & 70 & II & 3 & 12 \\
\hline P07 & $M$ & 31 & III & 3 & 17 \\
\hline P08 & $M$ & 36 & V & 3 & 20 \\
\hline P09 & $\mathrm{F}$ & 39 & III & 3 & 29 \\
\hline P10 & $M$ & 21 & II & 7 & 24 \\
\hline P11 & $M$ & 75 & V & 3 & 2 \\
\hline P12 & $M$ & 66 & II & 6 & 10 \\
\hline P13 & $M$ & 44 & II & 3 & 26 \\
\hline P14 & $M$ & 33 & II & 3 & 10 \\
\hline P15 & $M$ & 33 & II & 6 & 2 \\
\hline P16 & $M$ & 41 & II & 10 & 18 \\
\hline P17 & $M$ & 31 & III & 3 & 17 \\
\hline P18 & $M$ & 79 & $\mathrm{VI}$ & 3 & 12 \\
\hline P19 & $M$ & 33 & II & 6 & 2 \\
\hline P20 & $M$ & 27 & III & 3 & 40 \\
\hline P21 & $M$ & 41 & II & 14 & 2 \\
\hline P22 & $M$ & 58 & $\mathrm{VI}$ & 3 & 15 \\
\hline P23 & $M$ & 40 & II & 3 & 20 \\
\hline P24 & $M$ & 76 & II & 14 & 13 \\
\hline
\end{tabular}




\begin{tabular}{|c|c|c|c|c|c|c|c|}
\hline Pacient & $\begin{array}{c}\text { Počet } \\
\text { segmentů }\end{array}$ & $\begin{array}{l}\text { Počet použitých } \\
\text { segmentů }\end{array}$ & $\begin{array}{l}\text { Celkový počet } \\
\text { segmentů }\end{array}$ & $\begin{array}{l}\text { Využití } \\
\text { (\%) }\end{array}$ & $\begin{array}{l}\text { Měřený čas } \\
\text { (hod) }\end{array}$ & $\begin{array}{l}\text { Korelační } \\
\text { koeficient }\end{array}$ & $\begin{array}{c}\text { Směrnice } \\
\text { lineární regrese }\end{array}$ \\
\hline P01 & 4 & 45000 & 203522 & 22.1 & 10.7 & $0.73 \pm 0.09$ & $0.63 \pm 0.40$ \\
\hline P02 & 3 & 44000 & 234518 & 18.8 & 10.5 & $0.71 \pm 0.01$ & $0.69 \pm 0.14$ \\
\hline P03 & 10 & 180000 & 714118 & 25.2 & 42.9 & $0.74 \pm 0.10$ & $0.95 \pm 0.27$ \\
\hline P04 & 3 & 220000 & 531888 & 41.4 & 52.4 & $0.76 \pm 0.02$ & $1.25 \pm 0.60$ \\
\hline P05 & 9 & 273000 & 511853 & 53.4 & 65.1 & $0.76 \pm 0.11$ & $0.93 \pm 0.08$ \\
\hline P06 & 8 & 212000 & 779019 & 27.2 & 50.5 & $0.76 \pm 0.09$ & $0.81 \pm 0.18$ \\
\hline P07 & 5 & 156000 & 432682 & 36.1 & 37.1 & $0.72 \pm 0.09$ & $0.73 \pm 0.25$ \\
\hline P08 & 9 & 236000 & 944134 & 25.0 & 56.2 & $0.76 \pm 0.06$ & $0.62 \pm 0.16$ \\
\hline P09 & 2 & 84000 & 136773 & 61.4 & 20.2 & $0.72 \pm 0.16$ & $0.79 \pm 0.63$ \\
\hline P10 & 5 & 80000 & 474700 & 16.9 & 19.0 & $0.76 \pm 0.03$ & $1.20 \pm 0.21$ \\
\hline P11 & 1 & 10000 & 495318 & 2.0 & 2.4 & $0.64 \pm 0.00$ & $0.86 \pm 0.00$ \\
\hline P12 & 2 & 20000 & 362159 & 5.5 & 4.8 & $0.66 \pm 0.06$ & $0.75 \pm 0.20$ \\
\hline P13 & 1 & 6270 & 18770 & 33.4 & 1.5 & $0.81 \pm 0.00$ & $1.16 \pm 0.00$ \\
\hline P14 & 10 & 140300 & 433607 & 32.4 & 33.4 & $0.74 \pm 0.09$ & $0.90 \pm 0.21$ \\
\hline P15 & 4 & 46500 & 203512 & 22.8 & 11.1 & $0.80 \pm 0.06$ & $0.79 \pm 0.12$ \\
\hline P16 & 11 & 216000 & 405808 & 53.2 & 51.4 & $0.74 \pm 0.11$ & $0.89 \pm 0.26$ \\
\hline P17 & 1 & 56836 & 56836 & 100.0 & 13.5 & $0.89 \pm 0.00$ & $0.94 \pm 0.00$ \\
\hline P18 & 5 & 84000 & 320603 & 26.2 & 20.0 & $0.75 \pm 0.07$ & $0.79 \pm 0.09$ \\
\hline P19 & 2 & 30000 & 275091 & 10.9 & 7.1 & $0.66 \pm 0.04$ & $0.44 \pm 0.06$ \\
\hline P20 & 3 & 90000 & 463417 & 19.4 & 21.4 & $0.81 \pm 0.15$ & $0.90 \pm 0.20$ \\
\hline P21 & 2 & 20000 & 338910 & 5.9 & 4.8 & $0.73 \pm 0.12$ & $1.26 \pm 0.58$ \\
\hline $\mathrm{P} 22$ & 2 & 40000 & 505968 & 7.9 & 9.5 & $0.71 \pm 0.01$ & $0.76 \pm 0.21$ \\
\hline $\mathrm{P} 23$ & 1 & 10000 & 431123 & 2.3 & 2.4 & $0.71 \pm 0.00$ & $0.78 \pm 0.00$ \\
\hline P24 & 5 & 111000 & 141156 & 78.6 & 26.4 & $0.71 \pm 0.03$ & $0.92 \pm 0.07$ \\
\hline Celkem & 108 & 2411206 & 9415485 & NA & 574.1 & 0.86 & 0.68 \\
\hline Průmèr & 4.5 & 100467 & 392312 & 25.6 & 23.9 & $0.74 \pm 0.08$ & $0.86 \pm 0.27$ \\
\hline
\end{tabular}




\section{Literatura}

[1.] Canac N, Jalaleddini K, Thorpe SG, Thibeault CM, Hamilton RB. Review: pathophysiology of intracranial hypertension and noninvasive intracranial pressure monitoring. Fluids Barriers CNS. 2020;17(1):40. doi:10.1186/s12987-020-00201-8

[2.] Geeraerts T, Duranteau J, Benhamou D. Ocular sonography in patients with raised intracranial pressure: the papilloedema revisited. Crit Care Lond Engl. 2008;12(3):150. doi:10.1186/cc6893

[3.] Firsching R, Schütze M, Motschmann M, Behrens-Baumann W. Venous opthalmodynamometry: a noninvasive method for assessment of intracranial pressure. J Neurosurg. 2000;93(1):33-36. doi:10.3171/ jns.2000.93.1.0033

[4.] Bruce BB. Noninvasive assessment of cerebrospinal fluid pressure. J Neuro-Ophthalmol Off J North Am Neuro-Ophthalmol Soc. 2014;34(3):288-294. doi:10.1097/WNO.0000000000000153

[5.] Marshall LF, Barba D, Toole BM, Bowers SA. The oval pupil: clinical significance and relationship to intracranial hypertension. J Neurosurg. 1983;58(4):566-568. doi:10.3171/jns.1983.58.4.0566

[6.] Stettin E, Paulat K, Schulz C, Kunz U, Mauer UM. Noninvasive intracranial pressure measurement using infrasonic emissions from the tympanic membrane. J Clin Monit Comput. 2011;25(3):203-210. doi:10.1007/s10877-011-9297-x

[7.] Voss SE, Horton NJ, Tabucchi THP, Folowosele FO, Shera CA. Posture-induced changes in distortion-product otoacoustic emissions and the potential for noninvasive monitoring of changes in intracranial pressure. Neurocrit Care. 2006;4(3):251-257. doi:10.1385/NCC:4:3:251

[8.] Wu J, He W, Chen W-M, Zhu L. Research on simulation and experiment of noninvasive intracranial pressure monitoring based on acoustoelasticity effects. Med Devices AuckI NZ. 2013;6:123-131. doi:10.2147/ MDER.S47725

[9.] Amantini A, Carrai R, Lori S, et al. Neurophysiological monitoring in adult and pediatric intensive care. Minerva Anestesiol. 2012;78(9):1067-1075.

[10.] Lescot T, Naccache L, Bonnet MP, Abdennour L, Coriat P, Puybasset $L$. The relationship of intracranial pressure Lundberg waves to electroencephalograph fluctuations in patients with severe head trauma. Acta Neurochir (Wien). 2005;147(2):125-129; discussion 129. doi:10.1007/s00701-004-0355-8

[11.] Aaslid R, Markwalder TM, Nornes H. Noninvasive transcranial Doppler ultrasound recording of flow velocity in basal cerebral arteries. J Neurosurg. 1982;57(6):769-774. doi:10.3171/jns.1982.57.6.0769

[12.] Klingelhöfer J, Conrad B, Benecke R, Sander D. Intracranial flow patterns at increasing intracranial pressure. Klin Wochenschr. 1987;65(12):542-545. doi:10.1007/bf01727619

[13.] Rosenberg JB, Shiloh AL, Savel RH, Eisen LA. Non-invasive methods of estimating intracranial pressure. Neurocrit Care. 2011;15(3):599-608. doi:10.1007/s12028-011-9545-4

[14.] Behrens A, Lenfeldt N, Ambarki K, Malm J, Eklund A, Koskinen L-O. Transcranial Doppler pulsatility index: not an accurate method to assess intracranial pressure. Neurosurgery. 2010;66(6):1050-1057. doi:10.1227/01.NEU.0000369519.35932.F2

[15.] Mládek A, Gerla V, Šeba P, et al. From head micro-motions towards CSF dynamics and non-invasive intracranial pressure monitoring. Sci Rep. 2021;11(1):14349. doi:10.1038/s41598-021-93740-5

\section{MEASUREMENT OF NON-INVASIVE INTRACRANIAL PRESSURE BY MEANS OF DIFFERENTIAL GEOMETRY METHODS}

\section{Abstract}

Continual ICP monitoring is key in the neurointensive case. Although many different approaches have been proposed, catheter based ICP measurement remains the widely used golden standard. The intraparenchymal or intraventricular ICP measurement is, however, associated with the attendant risk of infection, hematoma formation, or seizures. The listed complications are the driving force for novel non-invasive ICP measurement methods investigation. Our non-invasive method is based on the calculation of differential geometry invariants of the head micro-motions in coma patients and its potential stems from the possibility of continuous ICP monitoring in the conservative TBI treatment. Moreover, we believe that our approach goes beyond traumatic neurosurgery and neurointensive care and is applicable also in other fields of medicine.

\section{Keywords}

intracranial pressure, ICP, dICP, cerebrospinal fluid, CSF, differential geometry, Cartan curvature, non-invasive measurement

\section{Kontakt}

RNDr. Mgr. et Mgr. Arnošt Mládek, Ph.D. Oddělení biokybernetiky, Ústav patologické fyziologie 1. LF UK e-mail:arnost.mladek@gmail.com

Doc. MUDr. RNDr. Ondřej Bradáč, Ph.D. Neurochirurgická klinika 2. LF UK a FN Motol 